\title{
HANS JONAS' FEEBLE THEODICY: HOW ON EARTH COULD GOD RETIRE?
}

\author{
PAUL CLAVIER \\ Ecole Normale Supérieure, Paris
}

\begin{abstract}
In this paper, we criticize Hans Jonas' analogy between God's power and the operation of physical forces. We wonder why, if omnipotence had proved to be "a self-contradictory concept", does Jonas still need to invoke the occurrence of horrendous evils to support the view that "God is not all powerful". We suggest that "God's retreating into himself in order to give room to the world, renouncing his being and divesting himself of his deity" are beautiful but inconsistent metaphors of creation. Our central claim is that God's alleged retirement, even if it were conceivable, would not the least diminish his responsibility in the occurrence of evil.
\end{abstract}

\section{INTRODUCTION: WHAT JONAS DOES NOT ARGUE}

Hans Jonas' famous Concept of God after Auschwitz (1984) is no doubt one of the most impressive philosophical reactions against the horrendous evils of the past century. On the one hand, Jonas presents his theodicy as a mythological scenario, in the mood of Plato's Timaeus. He describes it as "a piece of frankly speculative theology", and finally acknowledges it to be "but stammering". His lecture was conceived "like an answer [that could not be denied] to the long-gone cry [of victims] to a silent God". So, at first sight, Jonas' lecture does not seem to deserve any argumentative assessment. It looks like a moving tribute to the victims of Nazism, rather than like a conceptual analysis of how God's traditional attributes may or may not be jeopardized by the occurrence of horrendous evils. The reasons he gives for renouncing the omnipotence of God are more exciting reasons than justifying ones. I do not mean that exciting are 
forcedly bad reasons. They may dictate our compassionate behaviour in circumstances of distress. But they do not allow us to make conclusive statements about God's inability to intervene.

Anyway, on the other hand, Jonas argues that "on a purely logical plane ... omnipotence is a self contradictory concept"; and that "God's goodness is compatible with the existence of evil only if God is not all powerful". This is enough to submit Jonas' lecture to a conceptual inquiry into the coherence of his views. Of course, one might feel very uneasy, especially here in Poland, to take the horrendous sufferings as examples or counter-examples in an academic disputation on the problem of evil. As Eleonor Stump recently put it: "some evils are not fit objects for the academic exploration of the problem of evil"1. I cannot be but impressed by the deep sense of respect involved in this claim. But who will draw the line between academically bearable and unbearable instances of suffering? I will not.

Let us quickly recall the core of Jonas' claim. Given "the event of which Auschwitz has become the symbol", Jonas raises the terrible question: "And God let it happen. What God could let it happen?"2 At this stage, Jonas could have rephrased the traditional argument from horrendous evils: A perfectly good agent will prevent any evil unless it is morally permissible or unless he cannot prevent it.

(1) Some evils that occurred during WWII are in no way morally permissible.

(2) God did not prevent those non-permissible evils.

(3) God is perfectly good.

(4) God could not prevent those non-permissible evils.

(5) God is not omnipotent.

${ }^{1}$ Eleonor Stump, Wandering in Darkness, Oxford University Press, 2010, p. 16.

${ }^{2}$ The Journal of Religion, vol. 67, no. 1 (Jan 1987), Chicago University Press, p. 3. Jonas describes the destruction of human beings in the following terms: "Dehumanization by utter degradation and deprivation preceding their dying, no glimmer of dignity was left to the freights bound for final solution ..." Few reviews in the area of analytical philosophy. Huge influence in the Continental philosophy: E. Jüngel, Gottes ursprüngliches Anfangen als schöpferische Selbstbegrenzung. Ein Beitrag zum Gespräch mit Hans Jonas über den "Gottesbegriff nach Auschwitz", in: H. Deuser u.a. (eds.), Gottes Zukunft - Zukunft der Welt (FS Jürgen Moltmann), München 1986, 265-275. See Hans Hermann Henrix: "Powerlessness of God? A Critical Appraisal of Hans Jonas's Idea of God after Auschwitz" in Jewish Christian Relations (http://www.jcrelations.net/en/?item=757) 
This is not Jonas' strategy: because in order to perform it, he would have to justify premise (2). But he considers without discussion the premise (2) as obviously granted: this "wholesale annihilation, he says, [...] defied all possible endowment with meaning". "The victims, he adds, did not die for the sake of [anything]". Let's briefly comment upon this. Of course it would be shocking to claim that they died for the sake of the exercise of free-will, or that their death provided opportunities to show courage or patience. This kind of justification has become alien to contemporary sensitivity. But being shocking does not imply being false. Nevertheless, Jonas admits, without any further investigation, that some non-permissible evils have occurred, that ought to have been prevented, if only they could have been. This is of course begging the question. Clearly, Jonas does not make the shift of premises suggested by W. Rowe. ${ }^{3}$

Rowe construed the traditional argument from morally non-permissible evils as follows:

(1) There exist instances of intense suffering which an omnipotent, omniscient being could have prevented without thereby losing some greater good or permitting some evil equally bad or worse.

(2) An omniscient, wholly good being would prevent the occurrence of any intense suffering it could, unless it could not do so without thereby losing some greater good or permitting some evil equally bad or worse.

(3) There does not exist an omnipotent, omniscient, wholly good being. ${ }^{4}$

Rowe claimed it should be replaced, or at least balanced by the following: (not-3) There exists an omnipotent, omniscient, wholly good being.

${ }^{3}$ William Rowe, "The Problem of Evil and Some Varieties of Atheism", American Philosophical Quarterly, 16:4 (1979), pp. 335-41.

${ }^{4}$ A more precise account of the traditional atheist argument is to be found in Richard Swinburne: Providence and the Problem of Evil (Oxford University Press, 1998, pp. 1314), where premise (2) is rephrased in the following way: "A perfectly good being will never allow any morally bad state $\mathrm{E}$ to occur if he can prevent it, unless (i) allowing $\mathrm{E}$ to occur is something he has a right to do, (ii) allowing $\mathrm{E}$ (or a state of affairs as bad or worse) to occur is the only morally permissible way in which he can make possible the occurrence of a good state of affairs G, (iii) he does all else that he can to bring about G, and (iv) the expected value of allowing E, given (iii) is positive". 
(2) An omniscient, wholly good being would prevent the occurrence of any intense suffering it could, unless it could not do so without thereby losing some greater good or permitting some evil equally bad or worse.

(3) Therefore, it is not the case that (1) There exist instances of intense suffering which an omnipotent, omniscient being could have prevented without thereby losing some greater good or permitting some evil equally bad or worse.

The general strategy of the shift consists in beginning the new argument with the denial of the conclusion of the preceding one, and keeping the second premise, so that the denial of the first premise appears as a sound conclusion (for if $p \& q \rightarrow r$, then not- $r \& q \rightarrow$ not- $p$ ). This shift was inspired by "the G.E. Moore shift" used in dealing with the arguments of the sceptics. For example:

(1) We have no knowledge but of our impressions (as Hume puts it: "we never make a step beyond ourselves").

(2) If we have no knowledge but of our impressions, we have no true knowledge of the existence of this pencil.

(3) We have no true knowledge of the existence of this pencil. In this case, it will be easy to suggest that not-(3) is a more rational premise than (1). For one may argue that, if not-(3) is not granted, any higher -level knowledge such as (1) will a fortiori not hold. Or one may simply argue that not-(3) is a more basic belief anyway. Nevertheless, in the case of the argument from intense non-permissible sufferings, the G.E. Moore shift is not so easy to make. The existence of an omnipotent, omniscient and wholly good being is not a basic belief like, say, the belief that I have a true knowledge of the existence of this pencil. Defending the position of "friendly atheism" (that is of an atheist who does not take for definitely granted the existence of instances of intense suffering which an omnipotent, omniscient being could have prevented without thereby losing some greater good...) will not be so easy as making the G.E. Moore shift against skepticism. Indeed, skepticism about God's goodness or omnipotence is indeed a different kettle of fish. It requires at least discussing whether all the instances of intense suffering may be related to the occurrence of greater goods or the prevention of evils at least as bad...This is the challenge that every attempt in the field of theodicy has to face. But, here we come again, this is not Jonas' concern at all. 
Instead of discussing whether or to what extent some evils that occurred are permissible, Jonas prefers falling back, as he puts it, "on a speculative attempt" he had once ventured, a "myth of his own invention" (p. 3) ${ }^{5}$. It is the famous scenario of God "effacing himself from the world". This scenario is supposed to yield the general scheme of God's non-intervention, for which there will be no other account left, except God's absolute inability to intervene. Statement (6) is not, for Jonas, a conclusion to reach; it is a premise belonging to his conceptual scheme of God's attributes. This has to be emphasized. In order to grasp Jonas' theodicy, we have to realize that he is arguing from an emotivist point of view, which precludes in-principle every defence of God's omnipotence. This emotivist point of view is not fully irrelevant. Suppose you are to announce to someone the sudden death of a beloved relative. You would certainly not say: "Well, surely it would have been possible to prevent this heart attack, or to save the person from the crash, but the surgeon has estimated he did not have to intervene at any cost, even if he could. He preferred to save a defibrillator". On the contrary, you would probably say: "Sorry, the rescue team could not arrive in time. Then the surgeon did everything he could (which means: nobody could have done better)". And such an answer is supposed to comfort the mourning of the relative by endowing the tragic event with a kind of necessity. From such an emotivist point of view, it is not surprising that Jonas never discusses to what extent some evils are morally permissible. The very occurrence of any horrendous evil is for Jonas sufficient evidence that it is in no way morally permissible. In his view "horrendous" entails "morally nonpermissible". So that the occurrence of any horrendous suffering or evil precludes, a priori, God's omnipotence.

In the following, I am not presenting a theodicy, nor a defence, but only a peaceful counter-attack to Hans Jonas' denial of God's omnipotence. I will first examine in which terms Jonas conceives of God's relationship to the world. I will then examine his so-called "logical and ontological objection", according to which "omnipotence is a self-contradictory concept". I will then turn to consider his so termed "more theological, genuinely religious objection".

\footnotetext{
${ }^{5}$ Jonas refers to the "imaginative but credible conjecture that Plato allowed for the sphere beyond the knowable" (p. 4).
} 


\section{GOD AND THE WORLD : GENESIS REWRITTEN}

Let's pick out some major features of Jonas' mythical scenario:

(A) God chose to enter into the adventure of space and time. ${ }^{6}$

(B) The world is left to itself; its laws brook no interference.

(C) "In order that the world might be, and be for itself, God renounced his being, divesting himself of his deity".

Let's comment on these claims.

Taken literally, the first claim (A) would mean: once upon a time God was timeless and not limited to spatial conditions, and then he became himself subject to time and space. As Jonas puts it: "the eternal has "temporalized" himself and progressively becomes different through the actualizations of the world process". How can we make sense of this picture of a "becoming God" (p. 6)? Either God is supposed to be a temporal - though everlasting - being, in which case his being subject to time is in no way surprising. Changes would always have been possible in his internal or external operations (knowledge and actions). Otherwise,

6 "In the beginning, for unknowable reasons, the ground of being, or the Divine, chose to give itself over to the chance and risk and endless variety of becoming; And wholly so: entering into the adventure of space and time, the deity held back nothing of itself: no uncommitted or unimpaired part remained to direct, correct, and ultimately guarantee the devious working-out of its destiny in creation. On this unconditional immanence the modern temper insists. It is its courage or despair, in any case its bitter honesty, to take our being-in-the world seriously: to view the world as left to itself, its laws as brooking no interference, and the rigour of our belonging to it as not softened by extramundane providence." (p. 4)

7 "The same our myth postulates for God's being in the world. Not, however, in the sense of pantheistic immanence: if world and God are simply the same, the world at each moment and in each state represents his fullness, and God can neither lose nor gain. Rather, in order that the world might be, and be for itself, God renounced his being, divesting himself of his deity - to receive it back from the Odyssey of time weighted with the chance harvest of unforeseeable temporal experience: transfigured or possibly even disfigured by it. In such self-forfeiture of divine integrity for the sake of unprejudiced becoming, no other foreknowledge can be admitted than that of possibilities which cosmic being offers in its own terms: to these, God committed his cause in effacing himself for the world." (p. 4)

8 "Whatever the "primordial" conditions of the Godhead, he ceased to be selfcontained once he let himself in for the existence of a world by creating such a world or letting it come to be" (p. 7). 
God is supposed to be timeless, and it is hard to conceive of a timeless being who would really change, or become. If at $t, x$ becomes temporal, $x$ was certainly mutable at least just before $t$, and if $x$ is mutable, $x$ is temporal. If $x$ was not mutable before he became suddenly temporal, no change could occur to him. We may even, thanks to Eleonore Stump and Norman Kretzmann, make sense of an omniscient eternal entity being aware of all temporal events at once, and nevertheless understanding that these events occur sequentially. But it seems hard to conceive of a genuinely immutable being deciding not to be immutable any more. It may seem easier to make sense of "God entering into the adventure of space", because becoming spatial could simply mean limiting one's causal power to a certain area. This does not necessarily mean that God would have an embodied existence after existing like a pure spirit. Nevertheless, statement (A) is far from being self-evident.

Then you get the view (B) that God cannot intervene in the course of worldly states of affairs. He neither allows, nor prevents, nor favours any event. He just passively attends the show that ends up turning into something horrific. Let us simply emphasize that this allegedly forced passiveness dismisses any inquiry into the question of why God allows evil. He is not in a position to allow or to prevent whatsoever.

Then there is the third claim, combining (A) and (B), i.e. (C): that the world could not exist or be "for itself" without God divesting his deity. Claim (C) seems to make a statement that God sustaining the world implies the non-existence of the world for itself, and then, the existence of the world for itself requires God stopping to sustain its existence. Here we meet some serious objections:

Firstly, how can a not-self-existing world acquire self-existence? If God exerts a creating, that is a generating and sustaining causal power, then he is constantly intervening, even if he chooses not to break the course of the laws of nature or of human acts of free-will. Autonomy of secondary causes does not entail self-existence. If, on the contrary, God does not sustain any existence any more, then the world has to exist on its own. But if the world has not always been self existing, then something or someone must have made it self-existent. And then, owing its selfexistence to something else, the world still depends on a maker of its self-existence. 
Secondly, how can a creator and sustainer of everything that there is renounce his being and divest himself of his deity? How can we conceive of a retired creative power? Generally speaking, the framework of theistic metaphysics is the following: self-existence is denied to objects and persons, but the ultimate explanation of their being and operating is a self-existent agent, namely God. God is not only a generating, but also a sustaining cause of everything that there is. As James F. Ross puts it, "to create is to effect the being of other things". A most celebrated issue is to ask whether the created beings could continue to exist on their own. As long as creation is conceived analogically with human or physical production, it seems they can. Just like houses can survive architects and masons. But this analogy may prove to be false, since creation requires no pre-existent matter and does not require necessarily that the creatures exist after having not existed As Philip Quinn puts it:

For God to create or conserve an individual at an instant is merely for him at that instant to bring about the existence of the individual at the instant ... Seen in this light, the question of whether the cosmos of contingent things was introduced into existence ex nihilo after a period of time when nothing contingent existed becomes relatively unimportant for theistic orthodoxy. ${ }^{10}$

How can we understand statement (C)? Either it belongs to God's deity that he freely chooses to sustain or to annihilate the existence of creatures, in which case God divesting his deity or renouncing his being would mean the end of the world. Or, God's sustaining the very existence of creatures is not essential to him, and then renouncing his being does not make any difference to us. In both cases, the world being left to itself is not a consistent view.

Thirdly, even if it were conceivable, it still would raise a problem of responsibility concerning the occurrence of evil... The fact that God cannot intervene is not as such enough to extinguish his responsibility. For either he would have freely chosen that things and persons should continue to exist and to operate by themselves, or not. Suppose now that

9 James F. Ross, “Creation”, in The Journal of Philosophy, vol. 77, no. 10, 1980, p. 626.

${ }^{10}$ Philip Quinn, "Divine Conservation, Continuous Creation, and Human Action", in The Existence and Nature of God, ed. Alfred J. Freddoso (Notre Dame, Ind.: University of Notre Dame Press, 1983), p. 70. 
he has chosen not to be able to intervene any more. In this case, he will be like a man who has chosen to drink so much that he cannot feel responsible for anything anymore. Although he could not in any way come to the rescue, he would nevertheless remain responsible for whatever happens, even if he cannot exert any control on the situation. Of course, if God had no choice, if necessarily a world had to exist on its own, God is not responsible. But if the world is self-existent, there is no need for a God, and the problem of evil should be solved without this factor.

Jonas then explores the consequences "of the idea of the becoming God":

[...] this caring God is not a sorcerer who, in the act of caring also provides the fulfilment of his concern: he has left something for other agents to do and thereby has made his care dependent on them. He is therefore also an endangered God, a God who runs a risk (pp. 7-8).

Well, it should be clear that leaving something for other agents to do does not imply that you cannot intervene, or that you cannot control the risk you have chosen to run. There is a classical issue, whether beyond God's conservation of created entities, a general concurrence with secondary causes is further required. Even if created substances are true causal contributors, since they are not self-existent, they can hardly be self-operating. ${ }^{11}$ On the contrary, Jonas seems to imply that God cannot intervene any more at all. So he has not only left something, but everything for other agents to do. Surely, such a God would not be "a sorcerer who, in the act of caring also provides the fulfilment of his concern". But he would be a sorcerer's apprentice, who has lost all control of the situation. Once again, although he would not be in charge of the situation anymore, he would nevertheless remain responsible for it.

How does Jonas justify his view? As he puts it: "Clearly that must be so, or else the world would be in a condition of permanent perfection" (p. 8). So, for Jonas, God's omnipotence is necessarily bound with the world being in a perfect condition. And, since the occurrence of evil is interpreted as a not permissible imperfection, God's omnipotence is ipso facto denied.

11 Alfred J. Freddoso, God's General Concurrence with Secondary Causes: Why Conservation is not Enough, in James E. Tomberlin, ed., Philosophical Perspectives, 5, Philosophy of Religion, Atascadero, Calif.: Ridgeview Publishing, 1991. Freddoso explains precisely how concurrentism is neither occasionalism nor mere conservatism. 


\section{OMNIPOTENCE AS A SELF-CONTRADICTORY CONCEPT}

Let's now turn to the second main consideration. Jonas vindicates what he labels "the most critical point in [his] speculative, theological venture: this is not an omnipotent God". But quite surprisingly, the first attack against God's omnipotence is not an argument from evil. Jonas pretends to "argue, on a purely logical plane, by pointing out the paradox in the idea of absolute power" (p. 8). (It should not be a surprise anymore, if I am right in supposing that Jonas never argues from evil to God's limited power, but reacts emotionally against the non-intervention of a good being). "From the very concept of power, it follows that omnipotence is a self-contradictory, self-destructive, indeed, senseless concept." How does Jonas elaborate this point?

Absolute, total power means power not limited by anything, not even by the mere existence of something other than the possessor of that power; for the very existence of such another would already constitute a limitation, and the one would have to annihilate it so as to save its absoluteness. Absolute power then, in its solitude, has no object on which to act. But as objectless power it is a powerless power, cancelling itself out: "all" equals "zero" here. The existence of another object limits the power of the most powerful agent at the same time that it allows it to be an agent. In brief, power as such is a relational concept and requires relation. (p. 8)

Seemingly, Jonas mingles here two different concepts of power. Jonas misses the distinction between what we should term a metaphysical creative power: the ability to bring about any logically contingent state of affairs, and what we should term a physical comparative power: the capacity to overcome the strength of something already existing. The very fact that an external operation usually requires an object upon which you act does not necessarily imply that the object will resist your action. And in the case of creation ex nihilo, there is nothing upon which the creator exerts his creative power. Effecting the very being of other things is not affecting some already available substratum, as P. Geach's famous definition of creation clearly emphasizes:

God creates $\mathrm{x}=$ Def (God brings about that $(\exists \mathrm{x})(\mathrm{x}$ is an $\mathrm{A})$ ) $\& \operatorname{Not}((\exists x)$ God brings about that $(x$ is an $A)){ }^{12}$

${ }^{12}$ P. T. Geach, God and the Soul, "Causality and Creation" (London: Routledge and Kegan Paul), 1969, p. 83. 
But if one defines power like Jonas does, God could not even create. In fact, as we shall notice, Jonas admits that God cannot create without ipso facto losing his creative power! Jonas elaborates this view further: "Again, power meeting no resistance in its relatum is equal to no power at all: power is exercised only in relation to something that itself has power". ${ }^{13}$ Jonas' conception rests upon an analogy:

Just as, in physics, force without resistance - that is, counterforce remains empty, so in metaphysics does power without counterpower, unequal as the latter may be.

He then combines the notion of power and the concept of existence by itself:

That, therefore, on which power acts must have a power of its own, even if that power derives from the first and was initially granted to it, as one with its existence, by a self-renunciation of limitless power - that is, in the act of creation.

Jonas concludes:

In short, it cannot be that all power is on one side of one agent only.

Power must be divided so that there be any power at all. (p. 9)

We could argue that Jonas' conception of absolute power is resting on a false analogy between the metaphysical power of an agent, and the physical concept of force. But even if this analogy could hold, we could make an answer inspired by Swinburne's solution to the Paradox of the Stone. True, if God created a stone that he subsequently could not lift, there would be a task he cannot perform. And then it would be pointless to argue that the phrase "such a stone created by God as he cannot subsequently lift it" has no reference, because this phrase has necessarily no reference only under the presupposition that God is omnipotent. And nevertheless, creating such a stone is not something God has to do in order to prove his omnipotence. It is sufficient that he can, it is not required that he will. If he did it, he would certainly compromise his ability "to bring about any logically contingent state of affairs". As Swinburne puts

\footnotetext{
${ }^{13}$ Power, unless otiose, consists in the capacity to overcome something; and something's existence as such is enough to provide this condition. For existence means resistance and thus opposing force. (p. 9)
} 
it: "In creating the universe, God is merely exercising his omnipotence, yet not in a way so as to limit his future exercise of it". ${ }^{14}$

Well it seems that in Jonas' view, creating the world is like creating only stones that he will not be able to lift. This view is shared by many philosophers, like Sartre who considers that a created being is a contradiction. In order to exist truly, anything has to exist independently from its creator:

If being exists as over against God, it is its own support, it does not preserve the least trace of divine creation [...] This is equivalent to saying that being is uncreated. ${ }^{15}$

One may of course disagree with such a prejudicial view that is heavily begging the question of whether anything could truly exist while owing its existence to a creator.

\section{A MORE THEOLOGICAL, GENUINELY RELIGIOUS OBJECTION}

Then Jonas purports, he says, "a more theological, genuinely religious objection to the idea of absolute and unlimited divine omnipotence". Does it mean that the so called purely logical objection was not relevant? Jonas claims, very traditionally, that

Goodness is inalienable from the concept of God and not open to qualification. But God's [...] goodness must be compatible with the existence of evil, and this is only if he is not all powerful. (p. 9)

Here we meet a problem: if the concept of absolute power had already proved to be self-contradictory, surely it would no longer be worth assessing whether the occurrence of some evils is compatible with God's omnipotence. Whatever evils might occur, God could not be all powerful anyway. In fact, even in a perfect peaceful world, there would be no place for an omnipotent agent. So our question is: why does Jonas pretend that the three attributes of absolute goodness, absolute power, and intelligibility "stand in such a logical relation to one another that the

${ }^{14}$ R. Swinburne, The Coherence of Theism, Oxford University Press, revised edition, 1993, p. 163.

${ }^{15}$ Introduction to Being and Nothingness, transl. H. E. Barnes 1958, University Paperbacks, Routledge 2000, p. xl. 
conjunction of any two of them excludes the third", if absolute power is already excluded?

The preceding strategy argued that omnipotence is self-contradictory. But now, Jonas seems to fall back to his mythical framework: omnipotence would imply a perfect world. The world is not perfect, so God is not omnipotent. How can we make sense with these two incompatible strategies?

Jonas seems to suppose that God's non-omnipotence does exempt him from any responsibility towards horrendous evils. But not being omnipotent is not as such a sufficient excuse for not preventing certain evils. One could conceive of a limited power which would remain able to prevent any non permissible bad state of affairs. Conversely, one could conceive of an omnipotent being that could not prevent the occurrence of morally non permissible evils (given that these evils would be logically necessary states). So the issue of whether omnipotence is or is not a selfcontradictory power is not always relevant concerning the problem of non permissible evils.

Only if God is fully unable to intervene will he have a cast-iron alibi. Because Jonas does not want to discuss to what extent some horrendous evils could have nevertheless been permitted (not prevented), he prefers to annihilate God's power to intervene. As Plato put it: "Theos anaitios" (God is not responsible anymore).

God's power [is seen] as limited by something whose being in its own right and whose power to act on its own authority he himself acknowledges [...] We have the choice to interpret this as a voluntary concession on God's part, which he is free to revoke at will - that is, as the restraint of power that he still and always possesses in full but, for the sake of creation's own autonomous right, chooses not fully to employ.

This interpretation seems to me to be the appropriate framework for a correct defence. But this is not Jonas' interpretation. He argues on the contrary that if God were still endowed with omnipotence, he could not have chosen the restraint of his power for the sake of creation's own autonomous right. According to Jonas, God had no choice: in order that the world might be, he had to renounce his omnipotence (although it is difficult to conceive of the world's self-sustaining and self-generating). But, one could argue, didn't he still have the choice to create the world 
or not? Then he remains chiefly responsible for everything that occurs subsequently, including the misuse of free-will. Let us turn to how Jonas describes God's retirement:

Somehow he has, by an act of either inscrutable wisdom or love or whatever else the divine motive may have been, forgone the guaranteeing of his self-satisfaction by his own power, after he has first, by the act of creation itself, forgone being "all in all". (p. 8) 16 $^{16}$

Two different topics should be disentangled here. First, it is not clear at all that creation in itself entails a forgoing to be all in all. For the phrase "all in all" does not refer to the same reality, given the creation or not. If no world is created, God is the sole being. He is. We may say that he is all in all. This may refer to the doctrine of God being his attributes, or simply to the fact that there is nothing but God. He is all that there is. That's all. Given a created world, are we to say that God is not "all in all" anymore? Not at all, if I may say. God is not anymore everything that exists, but there is no reason why he shouldn't remain the same as he was. He is at least everything that used to exist before or apart from the creation of the world. Maybe creating the world adds something to his attributes (as an extrinsic property - there is a traditional issue whether creation represents a change in God, which of course is connected with other issues like divine immutability or divine timelessness). But why should creation imply a loss of God's power or existence? Jonas nevertheless steadily sticks to it: "divine-self restriction" is a necessary condition of the being of "self-determined creatures". Jonas develops this view:

self-limitation [of a unique divine principle] permits (gives 'room' to) the existence and autonomy of a world [...] Creation was that act of absolute

\footnotetext{
${ }^{16}$ Jonas seems to imply that only a becoming God, a suffering God, can be said to take care of human existence "the relation of God to the world from the moment of the creation, and certainly from the creation of man on, involves suffering from the part of God." This view "bound up with the concepts of a suffering and a becoming God is that of a caring God - a God not remote and detached and self-contained but involved with what he cares for". (p. 7) Cf. p. 8: "He is therefore also an endangered God, a God who runs a risk. Clearly that must be so, or else the world would be in a condition of permanent perfection. The fact that it is not bespeaks one of two things: that either the One God does not exist (though more than one may), or that the One has given to an agency other than himself, though created by him, a power and right to act on its own and therewith a scope for at least codetermining that which is a concern of his."
} 
sovereigntywith whichitconsented, forthesakeofself-determinedfinitude, to be absolute no more - an act, therefore, of divine self-restriction. (p. 11) By forgoing its own inviolateness, the eternal ground allowed the world to be. To this self-denial all creation owes its existence and with it has received all there is to receive from beyond. (p.12)

All this refers to the cosmogonic concept of Lurianic Kabbalah (TzimTzum), which Jonas summarizes in the following terms:

To make room for the world, the En-Sof (Infinite; literally, No End) of the beginning had to contract himself so that, vacated by him, empty space could expand outside of him: the "Nothing" in which and from which God then could create the world. Without this retreat into himself, there could be no "other" outside God, and only his continued holdinghimself-in preserves the finite things from losing their separate being again into the divine "all in all". (p. 12) $)^{17}$

Here we find a picturesque metaphor of creation, but it rests once more on a fallacious analogy between the bringing about of the very existence of things, and the normal condition of production for embodied persons or material processes. Making something exist is described in terms of the separate locating of creator and creature. The effecting of the very existence of creatures is viewed as letting someone entering a lift and being obliged to renounce occupying the whole room of the lift.

The cosmogonic concept of Tzim-Tzum supposes that an $x$ different from God may exist if $x$ is outside God. Since God is supposed to have occupied all the space before $x$ came to be, God has then to evacuate enough place, so that some new separate creature may move into the empty space, released by his departure. Well, if God is not a spatial being, he has no need to retreat in himself in order to make room for whatever he creates. But even if God were a spatial being, occupying the whole space at some time, he could create other spatial beings. He could make

${ }^{17}$ Sometimes Jonas argues another way that: "the mere permitting of human freedom involved a renouncing of sole divine power henceforth". (p. 11) But as we have already noticed, renouncing to exert one's power on certain occasions does not imply being divested of this power. The statement according to which God, "for the time of the ongoing world process - has divested himself of any power to interfere with the physical course of things" (p. 10) rather expresses Jonas' (and our) difficulty to bear the divine permission of horrendous suffering. 
things exist endowed with extension, that is to say he could make things and room, without having to make room for things to exist. If God is able to bring about the very existence of creatures, surely he is able to make an empty space in which he will locate them, or if space is relative to objects, creating them will be ipso facto creating their spatial or extensional relations. So there is no need to claim that creation entails the retirement of the creator. As long as something does not exist on its own, it needs a sustaining cause. And, once more, how could anything get rid of its sustaining cause of existence?

The conceptual framework of Tzim-Tzum, as presented by Hans Jonas ${ }^{18}$, is surely fascinating, but it does not hold. It may express metaphorically the discretion of a God who endows his creatures with a large autonomy, but it does not describe the true metaphysical structure of a created world.

Let's now turn to the last point. In order to emphasize his denial of God's omnipotence, Jonas argues from the quantity of evil:

in view of the enormity of what $[\ldots]$ some [men] inflict on innocent others, one would expect the good God at times to break his own, however stringent, rule of restraint and intervene with a saving miracle.

Curiously, Jonas seems not to exclude any more such an intervention: an occasional miracle, i. e., extramundane intervention in the closed causality of the physical realm, is not incompatible with the general validity of the laws of nature (rare exceptions do not void empirical rules) and might even, by all appearances, perfectly conform to them. (p. 10, footnote) But no saving miracle occurred. [...] God remained silent [...] God was silent. [...] Not because he chose not to, but because he could not intervene did he fail to intervene. (p. 10)

So Jonas seems to argue from the enormity of suffering to God's inability to intervene. This raises once more a terrible problem of drawing a line. There is no reason why God should intervene for, let's say, 6 million victims of Nazism but not for 5.9. And if 5.9 million victims would have justified a saving miracle, why should not 5.5? What makes the difference? And

${ }^{18}$ Yehuda Gellmann kindly suggests to me that the true Lurianic account does not extinguish every link between creator and created world, which is a more consistent view.. But here I am just considering Hans Jonas' use of the Tzim-Tzum. 
so on. I beg your pardon for this terrific calculus. It is a macabre instance of the Sorites paradox. Of course, each additional victim increases the magnitude of evil. But does it change the case for God's omnipotence? Surely God's non-intervention, for example in cases involving the cruel murdering of babies, is shocking. But is there a line to be drawn, beyond which we are justified to say: beyond this limit, God's non-intervention entails his powerlessness to intervene? It does not seem so. There is no critical number of cries for help beyond which you may conclude: if God remains silent, then he must be mute (or dumb). My suggestion is: if God intervenes, (and surely he does, since sometimes horrendous murdering projects seem to have been stopped by supernatural means) it cannot be just for numerical reasons. Either God has a morally sufficient reason to allow such grievous evils, or not.

There is also another problem, connected with Robert Kane's objection to Frankfurt examples: how could God intervene in due time? ${ }^{19}$ Those who claim that God's not preventing the occurrence of a horrendous murdering is evidence for God's limited power should tell us when God ought to have intervened in order to prevent the murdering. Either God lets most people exert their free-will, despite some awful consequences, and then, in order to save God's goodness and omnipotence, you will have to explain to what extent some horrendous evils may be nevertheless considered to be morally permissible (although emotionally unbearable). Or, you

${ }^{19}$ Cf. R. Kane's so called "Indeterministic World Objection": "Suppose Jones's choice is undetermined up to the moment when it occurs, [...]. Then a Frankfurt controller, such as Black, would face a problem in attempting to control Jones's choice. For if it is undetermined up to the moment when he chooses whether Jones will choose A or B, then the controller Black cannot know before Jones actually chooses what Jones is going to do. Black may wait until Jones actually chooses in order to see what Jones is going to do. But then it will be too late for Black to intervene. Jones will be responsible for the choice in that case, since Black stayed out of it. But Jones will also have had alternative possibilities, since Jones's choice of A or B was undetermined and therefore it could have gone either way. Suppose, by contrast, Black wants to ensure that Jones will make the choice Black wants (choice A). Then Black cannot stay out of it until Jones chooses. He must instead act in advance to bring it about that Jones chooses A. In that case, Jones will indeed have no alternative possibilities, but neither will Jones be responsible for the outcome. Black will be responsible since Black will have intervened in order to bring it about that Jones would choose as Black wanted" (R. Kane, Free Will and Values, Albany, NY: SUNY Press 1985, p. 51). 
pretend that God's goodness and omnipotence can only be saved if he prevents these horrendous murders. But in order to prevent an event, you have to be sure that it will occur anyway if you do not intervene (or rather that it would occur if you did not intervene), which implies that the world is deterministic, at least concerning some events that we suppose are connected with moral responsibility. So either you have to wait for a "flicker of freedom" to occur, and then your intervention will destroy the effectiveness of moral responsibility, or you have to grant that there is no free-will anyway. Either God is Black (the Frankfurt controller), or God is out. Instead of this black/out dilemma, I stick to the suggestion that God's non-intervention is no evidence for his inability to intervene. May I add that I can hardly conceive of a true hope in salvation, if a tired or a retired God is supposed to do the job.

To conclude: the way that Jonas argues against God's omnipotence shows much compassion, but is not convincing. Creating the world is not like exerting a force upon something already existing. Second, it is hard to conceive of a retired creative power. How on earth could God, the very sustaining cause of everything what there is, retire? Thirdly, even if $\mathrm{He}$ could, this would not the least diminish his responsibility in the occurrence of evil. If, at some time, God was the generating and sustaining cause of the universe, then he remains chiefly responsible for every subsequent state of affairs, even when some of these states are brought about through the misuse of free-will.

In contemporary theodicies, God's retirement has become a stock excuse, but it remains a specious one. God's absence note is not acceptable. 